
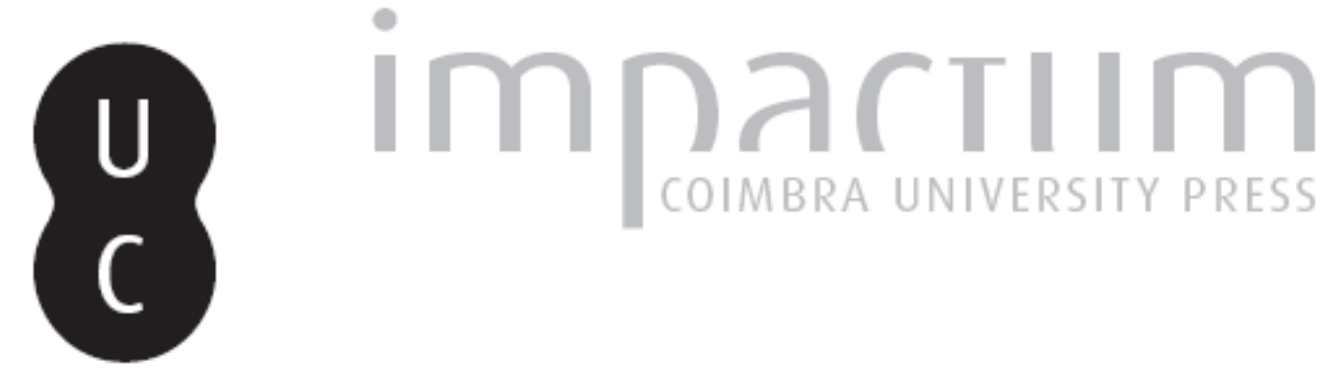

The Atlantic outermost regions, the furthest frontiers of Europe?

Autor(es): $\quad$ Valente, Isabel Maria Freitas

Publicado por: Centro de Informação Europe Direct de Aveiro; Centro de Estudos

Interdisciplinares do Século XX

URL

persistente:

URI:http://hdl.handle.net/10316.2/37109

DOI:

DOI:http://dx.doi.org/10.14195/1647-6336_12_4

Accessed : $\quad$ 26-Apr-2023 09:55:21

A navegação consulta e descarregamento dos títulos inseridos nas Bibliotecas Digitais UC Digitalis, UC Pombalina e UC Impactum, pressupõem a aceitação plena e sem reservas dos Termos e Condições de Uso destas Bibliotecas Digitais, disponíveis em https://digitalis.uc.pt/pt-pt/termos.

Conforme exposto nos referidos Termos e Condições de Uso, o descarregamento de títulos de acesso restrito requer uma licença válida de autorização devendo o utilizador aceder ao(s) documento(s) a partir de um endereço de IP da instituição detentora da supramencionada licença.

Ao utilizador é apenas permitido o descarregamento para uso pessoal, pelo que o emprego do(s) título(s) descarregado(s) para outro fim, designadamente comercial, carece de autorização do respetivo autor ou editor da obra.

Na medida em que todas as obras da UC Digitalis se encontram protegidas pelo Código do Direito de Autor e Direitos Conexos e demais legislação aplicável, toda a cópia, parcial ou total, deste documento, nos casos em que é legalmente admitida, deverá conter ou fazer-se acompanhar por este aviso. 
DEBATER

A EUROPA

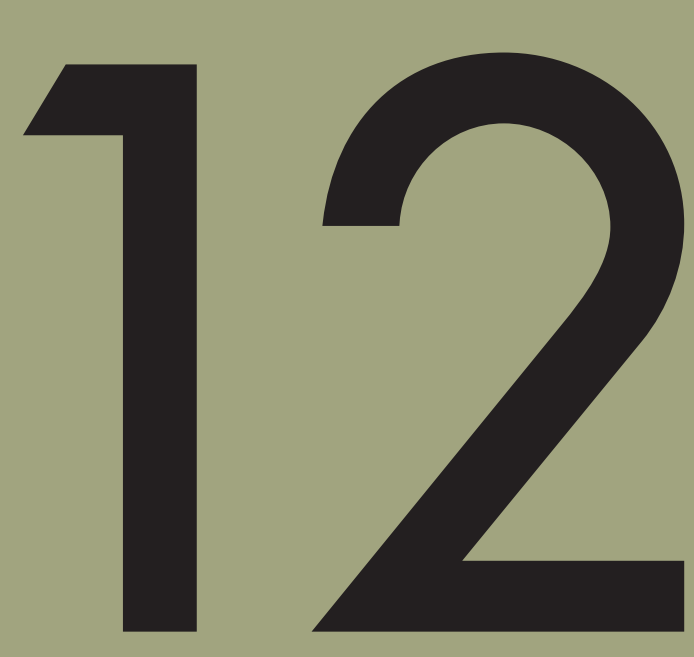

jan-jun 2015

POLITICAS REGIONAIS DA UE

EU REGIONAL POLICIES 


\title{
The Atlantic outermost regions, the furthest frontiers of Europe?
}

\author{
Isabel Maria Freitas Valente \\ Research Fellow at the Interdisciplinary Research Centre of the twentieth century \\ University of Coimbra - CEIS20 \\ Executive Director of the Scientific Journal Debater a Europa \\ Member of Team Europe of the European Commission \\ E-mail: valente.isa@gmail.com
}

\begin{abstract}
We set out to examine the importance of the Atlantic outermost in the context of the European Union, focusing on the role it plays as an outermost frontier of the European project, and, even more specifically, the Portuguese Autonomous Regions - the Azores and Madeira.
\end{abstract}

Keywords: European Union; outermost regions; Atlantic; Azores; Madeira

There are places where we feel the "weight of history" profoundly. One such place is certainly the Atlantic islands. These are like the sacred thresholds of the time when, for a brief moment, we can quite easily be transported to the dimension of a past with a special meaning.

As Pedro Faria e Castro considers "coastal islands have had a special place in the security of continents throughout history, particularly for Europe. Chasle de la Touche said in the 19th century, referring to the relative importance of Belle-Île in the French region of Brittany, that that island was too far from the Brittany coast to help in its 
defence, but it was a potential stronghold from which to attack it, should it be taken by an enemy."

These islands, scattered around the world, are one of the pillars of European expansion and in many cases they are still the ultimate geostrategic redoubts of the old maritime powers. The islands that still belong to European States - and there are many of them, spread around the Atlantic, Indian and Pacific oceans - are proof of the political value such States ascribe to them in a postcolonial world. Furthermore, they are essential pieces in European participation in the various aspects of the current process of globalisation.

Natural frontiers between the maritime horizon and the hinterland of European territory, legacies of the former colonial empires, the islands are strategic territories for the European Union (EU). They lend more meaning to the etymology of the word 'Europe', which takes us to Homer, for instance: "europé - what you see beyond." In fact they offer the chance of being the eyes and arms of the "Mother"2 (Europe) which open up like a bridge between the old continent and the rest of the world. They are therefore important economic centres. It can be said that in maritime terms they continue to play an important part, worldwide.

They serve as instruments of power projection because they are important points of advance support and provide a means to control certain routes and seas. If these islands are not particularly significant in terms of gross surface area as pieces of European States, the same cannot be said of their geopolitical significance. And this importance varies according to their location, more or less distant from mainland coasts.

While nationalism is reborn in the current crisis, apparently as a secure value, the ongoing process of globalisation favours the emergence of regions, which loom large as instruments for recreating the old nations, as well as a brand new European Union. As Avelino de Freitas Menezes observes, in this case "it shows the usefulness of Portugal's islands, whose insularity coexists with universality, which provides Europe with an enhanced Atlantic projection, regarded by everyone as essential when the time approaches for the rule of the sea, the greatest treasure for the future of humanity."

The EU islands cover a total surface area of $109423 \mathrm{~km}^{2}(3.4 \%$ of the EU) on

\footnotetext{
${ }^{1}$ CASTRO, Pedro Faria e - Perspectivar uma nova realidade política insular como resposta a uma melhor integração europeia. In VIEIRA, Alberto - As Ilhas e a Europa, a Europa das Ilhas. Região Autónoma da Madeira: CEHA, 2011. ISBN 978-972-8263-73-7.

2 europé is the epithet used by Homer to designate the father and lord of the gods.
} 
which live 14 million people (3.43\% of the EU). ${ }^{3}$ Both their geography and their demography make them specific territories of the European Union. As everyone knows, many of them are undisputable tourist attractions, while their specific conditions (away from mainland Europe, peripheral character, insularity, smaller market, etc.) keep them reliant on mainland territories, in many ways.

Island economies are weak because of the shortage of usable land, strong dependence on transport and communications infrastructure, limited natural resources and lack of skilled manpower. Their small-scale economies and reliance on a limited number of key sectors, demographic pressure and unemployment make them particularly vulnerable to internal and external economic crises.

Some of these islands benefit from a status explicitly recognised in Articles 349 and 355 of the Treaty on the Functioning of the European Union (TFEU) - the Outermost Regions (ORs). There are currently nine outermost regions:

- five French overseas departments - Martinique (in the Caribbean), Mayotte, Guadalupe, Réunion (Indian Ocean) and French Guiana (enclave in the Amazon forest);

- one French overseas collectivity - Saint Martin (in the Caribbean);

- two Portuguese autonomous regions - Madeira and Azores (Atlantic Ocean);

- one Spanish autonomous community - Canary Islands (Atlantic Ocean).

To make things clearer, it should be mentioned that until the end of 2011 the French overseas collectivity of Saint Barthélemy was also an outermost region of the European Union. However, thanks to its remoteness from metropolitan France, the specific legal status, the close economic ties with partners from the Americas and Barthélemy, it became one of the overseas countries and territories (OCTs) of the EU. This change came into force on 1 January 2012.

The OCTs consist of 26 countries and territories (including, until the end of 2013, Mayotte) - mostly small islands - outside of mainland Europe that have constitutional ties with one of the following Member States: Denmark, France, the Netherlands and the United Kingdom.

\footnotetext{
${ }^{3}$ Cf. Las Políticas Estructurales y los Territorios de Europa: Islas y Zonas Costeras, Folleto 2001, Unión Europea, Politica Regional.
} 
Article 355 of the Lisbon Treaty provides that the Council of Europe can change the status of the OCTs of France, Denmark and the Netherlands to an outermost region without requiring a treaty amendment.

As mentioned earlier, the situation of the ORs within the EU is complex and involves a number of specific features that complicate their development and their catching up with other regions in the Union. The ORs thus received and continue to receive special treatment within the EU to encourage the economic and social cohesion of the EU regions. Given the recognition of the existence and maybe the possible worsening of socioeconomic imbalances in these regions, the EU has undertaken a number of compensatory measures specifically designed to mitigate such imbalances and to take advantage of the exceptional geographical situation of the regions. The measures can be grouped in two categories: ${ }^{4}$ special economic and tax measures imposed indirectly, separate from the rest of the Union, and specific procurement schemes with price subsidy mechanisms for certain consumer goods. Most of these measures are included in programmes of options specific to remoteness and insularity, generally known as POSEI (the French overseas departments - POSEIDOM, in 1989; the Canary Islands - POSEICAN, in 1991, and the Azores and Madeira - POSEIMA, in 1991).

But it does not reduce the importance of the ORs to their demographic weight, the number of tourists visiting them or their agriculture. They also have merit and are rich because of their extraordinary cultural legacy, the diversity of their geographical setting and for the strategic role that have in protecting the sea routes of Europe and defending its external borders. In terms of globalisation, the European Union is the only continental region that can claim a presence in the heart of the Indian Ocean, the Caribbean and South America, precisely because of the ORs, whose good relations with neighbouring countries can benefit the EU and the development of its influence in these regions of the planet. Indeed, these regions are real bridges between the EU and Africa, MERCOSUL (agreement signed by Argentina, Brazil, Paraguay and Uruguay on 26 March 1991), and the United States.

In other words, the ORs represent a European presence in their geographical environment, lend it a global dimension and amount to its outpost. And they are "spearheads of Europe" for cultivating trade relations with their relevant neighbours as

\footnotetext{
${ }^{4}$ TAMAMES, Ramón - La Unión Europea. Madrid: Alianza Editorial, 1999, pp. 491-492.
} 
well as excellent places to establish certain high-tech activities, such as the European Space Agency, in Guiana and the Astrophysics Institute in the Canaries. It is thanks to the outermost regions that the European Union is the world's top maritime territory with an economic area of 25 million $\mathrm{km}^{2}$, of vital importance because of the enormous resources and potential it contains. ${ }^{5}$

In terms of the sea, the ORs represent more than half the exclusive economic zone (EEZ) of the EU, with a potential reserve of marine resources amounting to nearly 15 million $\mathrm{km}^{2}$. This is equivalent to a marine laboratory of unique depth that can be exploited by the EU in areas such as food security, combating climate change, energy and biotechnology. In terms of tourism, too, it is an exceptional asset thanks to its natural and cultural environment. In terms of tourism, too, it is an exceptional asset thanks to its natural and cultural environment. The ORs harbour a diversity of species and unique ecosystems that are extremely important for the biodiversity of the planet. Together with the overseas countries and territories, these regions have more endemic animal and plant species than the whole of mainland Europe, including over $20 \%$ of the world's coral reefs and lagoons. Their biodiversity represents potential in the areas of health, biomedicine and biopharmacy, cosmetics and many other sectors, including ecological building materials and timber. Some of the regions are suitable for developing sources of renewable energy, from biofuels to wind and solar power, and geothermal and photovoltaic energy. In terms of human capital, the ORs can provide workers who are better educated and more skilled, plus public services and skills that are more advanced than those of their neighbours, enabling them to supply services and expertise in sectors of high added value.

That is to say, the ORs are a European territorial presence in strategic parts of the globe possessed of exceptional geographical and geological features that make them first-rate laboratories for research and innovation in sectors of the future, such as:

\footnotetext{
${ }^{5}$ Among the many relevant works on the topic, for a better clarification of the general ideas of the process of European construction see: LASCHI, Guiliana - L' Unione Europea-Storia, istituzioni, politiche, Rome: Carocci, 2001, especially pp. 92-94; LANDUYT, Ariane (coord.) - L'Europe: fédération ou nations. Paris: SEDES, 1999. LANDUYT, Ariane (coord.) - Idee d'Europa e integrazione europea. Bologna: Il Mulino, 2004. RIBEIRO, Maria Manuela Tavares - A Ideia de Europa, uma perspectiva histórica. Coimbra, Quarteto Editora, 2003. RIBEIRO, Maria Manuela Tavares - "A Europa dos Intelectuais nos alvores do século XX". Estudos do Século XX, no. 2, CEIS20, Europa-Utopia-EuropaRealidade, coord. by Maria Manuela Tavares Ribeiro, Coimbra, Quarteto Editora, 2002, pp. 111-133; RIBEIRO, Maria Manuela Tavares - "Os Intelectuais e a Ideia de Europa". In Portugal e a Construção europeia, coord. by Maria Manuela Tavares Ribeiro, António Moreira Barbosa de Melo and Manuel Carlos Lopes Porto, Coimbra, Livraria Almedina, 2002, pp. 31-39.
} 
biodiversity and land and marine ecosystems, pharmacology, renewable energy and space sciences.

We can therefore emphasise that the specifics of these territories should be translated into an approach that values the potential for integration into the Community area. But their own characteristics must be seen as assets of the European Union in multiple domains and, as such, recognised and accepted by Member States. Basically, it amounts to acknowledging the wealth of diversity and pinpointing the irreplaceable contribution that these regions make because of the characteristics paradoxically linked to difficulties.

In this context, Community strategy to develop these regions must be boosted in an endeavour to create synergies and coherence between various Community policies that affect the ORs. A strategy that above all enhances their originality and exploits their unique situation.

Clearly, neither Europe nor America can do for us what only we can [and should] do: create wealth, spread it harmoniously, maintain freedom and independence. We should not forget, as Machiavelli observed, one thing gives rise to another and time governs them... ${ }^{6}$

Ending on an optimistic note, I quote Alberto João Jardim: the most remote territories of the Union lend it a universal dimension and should make a crucial contribution to the global affirmation of the European model of society and its values. It is in the interest of the Union itself to achieve this active frontier by developing the unique potential that exists in it. Let it be so.

\section{Bibliography}

AA .VV. - As Ilhas e a Europa. A Europa das Ilhas. Região Autónoma da Madeira: CEHA, 2011. ISBN 978-972-8263-73-7.

AA .VV. - Canarias en la Comunidad Europea. S.l.: Fundación Pedro García Cabrera, 1994.

\footnotetext{
${ }^{6}$ Machiavelli - O Príncipe. trans. Helena Ramos. Mem Martins: Europa América, D.L., 1991.
} 
AFISCRUP - Avaliação do Impacto dos Auxílios de Estado no Desenvolvimento das Regiões Ultraperiféricas da União Europeia, Junho 2007.

AMARAL, Carlos Pacheco - Autonomie régionale et relations internationales. Nouvelles dimensions de la Gouvernance Multilatérale. Paris: L'Harmattan, 2011.

AMARAL, Carlos Pacheco - Do Estado Soberano Ao Estado das Autonomias Regionalismo, subsidiariedade e autonomia para uma nova ideia de Estado. Porto: Ed. Afrontamento, 1998.

AMARAL, Carlos Pacheco - Do Estado Soberano ao Estado das Autonomias. Regionalismo, subsidiariedade e autonomia para uma nova ideia de Estado. Porto: Edições Afrontamento, 2002.

ASÍN, Cabrera, Mª A. - Islas y Archipiélagos en las Comunidades Europeas. Estudio de los regímenes jurídicos especiales con particular consideración de Canarias. Madrid: TECNOS, 1988.

BRIAL, Fabien - "La place des Régions Ultrapériphériques au sein de l'Union européenne ». In Cahiers de Droit Européen. Bruxelles, números5/6, 1998.

CONDE, Martínez, C. - La acción exterior de las Comunidades Autónomas. La institucionalización de los gobiernos territoriales y la integratión internacional. Tecnos: Madrid, 2009.

CASTRO, Pedro Faria e - Açores: Paradiplomacia e Autonomia. A participação das entidades na determinação e condução da política externa dos estados. Lisboa: ISCSP, 2015 .

CASTRO, Pedro Faria e - Perspectivar uma nova realidade política insular como resposta a uma melhor integração europeia. In VIEIRA, Alberto - As Ilhas e a Europa, a Europa das Ilhas. Região Autónoma da Madeira: CEHA, 2011. ISBN 978-972-826373-7. pp. 390-397. 
FERNÁNDEZ, Martin - Islas y Regiones Ultraperiféricas de la Unión Europea. La Tour-d'Aigues: L’Aube, 1999.

FORTUNA, Mário - “A problemática das regiões ultraperiféricas.” In Compêndio de Economia Regional. Coimbra: APDR, 2002, pp. 596-622.

HACHE, Jean-Didier - «Quel Statut pour les Îles d'Europe?» In Quel Statut pour les Îles d' Europe?/What Status for Europe's Islands?. Paris : L'Harmattan, 2000.

ISMERI EUROPE - Sumário Executivo Factores de crescimento nas Regiões Ultraperiféricas. $\quad$ S.1., 2011. [20/03/2015] Disponível em: http://ec.europa.eu/regional_policy/sources/docgener/studies/pdf/rup_growth/rup_growt h_sum_pt.pdf

GRM - Contribution de Madère pour l'avis d'initiative sur la problématique des RUPS face à l'article 299.2 du Traité. Funchal : s.e. Março, 2000.

GUILLIAUIMIN, Patrick - "La Dimension Ultrapériphérique de 1'Union Europeenne." In Quel Statut pour les Îles d'Europe?/What Status for Europe's Islands?, Paris : L'Harmattan, 2000, pp.103-128.

LASCHI, Guiliana - L' Unione Europea-Storia, istituzioni, politiche, Rome: Carocci, 2001.

LANDUYT, Ariane (coord.) - L'Europe: fédération ou nations. Paris: SEDES, 1999.

LANDUYT, Ariane (coord.) - Idee d'Europa e integrazione europea. Bologna: Il Mulino, 2004.

LÁYNEZ, Carlota González - Las regiones ultraperiféricas de la UE: evolución de las mismas como consecuencia de las políticas específicas aplicadas. Canarias como ejemplo. Madrid: Instituto de Estudios Europeos, 2005. 
RAA - Contributo no quadro do Livro Verde da Comissão Europeia sobre a "Coesão territorial europeia: tirar partido da diversidade territorial”, COM (2008) 616 Final, Fevereiro de 2009.

RAA - Parecer sobre "A Estratégia para as Rup: progressos e perspectivas futuras" COM (2007) 507 Final, Abril de 2008.

RIBEIRO, Maria Manuela Tavares - A Ideia de Europa, uma perspectiva histórica. Coimbra, Quarteto Editora, 2003.

RIBEIRO, Maria Manuela Tavares - "A Europa dos Intelectuais nos alvores do século XX". Estudos do Século XX, no. 2, CEIS20, Europa-Utopia-Europa-Realidade, coord. by Maria Manuela Tavares Ribeiro, Coimbra, Quarteto Editora, 2002, pp. 111-133.

RIBEIRO, Maria Manuela Tavares - "Os Intelectuais e a Ideia de Europa". In Portugal e a Construção europeia, coord. by Maria Manuela Tavares Ribeiro, António Moreira Barbosa de Melo and Manuel Carlos Lopes Porto, Coimbra, Livraria Almedina, 2002, pp. 31-39.

VALENTE, Isabel Maria Freitas - “Les Régions Ultrapériphériques de l’Union Européenne: Contexte, évaluation et perspectives". In The European Communities and the World. A Historical Perspective, coord. Giuliana Laschi, Bruxelas, Bern, Berlin, Frankfurt am Main, New York, Oxford, Wien, Peter Lang, 2014, pp. 47-62. ISBN 09442294 / 978-2-87574-135-6.

VALENTE, Isabel Maria Freitas - "Portugal e as Regiões Ultraperiféricas face à Política Marítima Integrada Europeia”. In Revista Debater a Europa, n. ${ }^{\circ} 10$, Aveiro, CIEDA/CEIS20, 2014, pp. 15-22. ISSN 1647-6336.

VALENTE, Isabel Maria Freitas - “A construção de um conceito - Região Ultraperiférica." In Revista Debater a Europa, n. ${ }^{\circ}$ 8, Aveiro, CIEDA/CEIS20, 2013, pp. 111-151. ISSN 1647-6336. 
VALENTE, Isabel Maria Freitas - “As Regiões Ultraperiféricas portuguesas e o discurso político", in Cenários da História, coord. Isabel Maria Freitas Valente e Joel Carlos de Souza Andrade, Campina Grande, EDUDCG, 2011, pp.145-157. ISBN 97885-8001-039-8.

VALENTE, Isabel Maria Freitas - "Ultraperiferia: Uma perspectiva Histórica". In VIEIRA, Alberto - As Ilhas e a Europa, a Europa das Ilhas, Madeira, Centro de Estudos de História do Atlântico Funchal, 2011, pp. 308-342. ISBN: 978-972-8263-737.

VALENTE, Isabel Maria Freitas - Conceito de Ultraperiferia - Génese e evolução. Coimbra: CEIS20, 2011. ISBN 978-972-8627287.

VALENTE, Isabel Maria Freitas - "Pensar uma outra Identidade Europeia: marítima, insular e ultraperiférica." In Debater a Europa, n. ${ }^{\circ}$, Aveiro, CIEDA/CIEJD, 2011, pp.17-31. ISSN 1647-6336.

VALENTE, Isabel Maria Freitas - "Regiões ultraperiféricas portuguesas: territórios estratégicos?" In RIBEIRO, Maria Manuela Tavares (coord.), 2009 (Re)Pensar a Europa, colecção Estudos sobre a Europa, n. ${ }^{\circ}$. Coimbra: Almedina/CEIS20, 2010, pp.47-68. ISBN 978-972-40-4130-8.

"Versões Consolidadas do Tratado da União Europeia e do Tratado sobre o Funcionamento da União Europeia", in Jornal Oficial da UE, n. 53, 30 de Março de 2010.

VALENTE, Isabel Maria Freitas - "Ultraperiphal Regions and European Citizenship." In Temas de Integração, $1^{\circ}$ e $2^{\circ}$ Semestre de 2009, n. 27 e 28, Coimbra, Almedina, 2010, pp.157-170. ISBN 9789724041940.

VALENTE, Isabel Maria Freitas - As Regiões Ultraperiféricas Portuguesas - Uma perspectiva histórica. Região Autónoma da Madeira: CEHA, 2009. ISBN 978-9728263-64-5. 